\title{
Interpretacje
}

\section{Niedostrzeżony wiersz Leśmiana}

Michał Głowiński

TEKSTY DRUGIE 2018, NR 5, S. 320-328

DOI: $10.18318 /$ td.2018.5.19

W przypadku wielkich poetów niemal każdy wiersz (być może poza juweniliami świecącymi odbitym światłem) zasługuje na osobne studium, na taką interpretację, która uwydatniałaby zarówno jego indywidualne właściwości, jak też kładłaby nacisk na tak lub czy inaczej charakteryzowane miejsce w całości dzieła. Przedmiotem rozważań winno zatem być to, co jest dla danego tekstu ogólnie właściwe, może i znamiona wyróżniające, indywidualne, w pewnych przypadkach niepowtarzalne. Leśmian niewątpliwie należy do tych poetów, których poszczególne utwory, choć zapewne nie w tak dużym wymiarze, na jaki by zasługiwały, były (i są) w sporej obfitości przedmiotami osobnych interpretacji, takich, w których ujawniano to, co dla jego stylu i - ogólnie - poetyki w analizowanym utworze charakterystyczne, jak i to, co wydaje się jedyne w swoim rodzaju, jednostkowe, a więc na swój sposób unikatowe. Także w dorobku tego poety istnieją utwory, którymi nikt się dotychczas nie zainteresował, ani autorzy prac o jego
Michał Głowiński -

(ur. 1934), emerytowany profesor Instytutu Badań Literackich, autor wielu książek z zakresu nauki o literaturze, esejów oraz książek o charakterze literackim i wspomnieniowym. 
stylu, poetyce, narracji, wizji świata, ani analitycy zajmujący się rozważaniami o poszczególnych wierszach.

Do grupy utworów niezauważonych, pomijanych bądź ze względu na to, że uznano je za mniej ważne czy mniej interesujące albo za niereprezentatywne należą Dwaj skazańcy, opowieść daleka od fantastyki, krótka, składają się na nią bowiem zaledwie dwie ośmiowersowe strofy. Zapewne nie będzie przesady w tym, gdy go określimy jako niedostrzeżony. Być może jakąś publikację przeoczyłem, wydaje mi się wszakże, iż w żadnej pracy o Leśmianie nie ma o wierszu tym nawet wzmianki, a jest on pod wieloma względami intrygujący, nasuwa różnego rodzaju pytania', aż prosi się o komentarz. Zwłaszcza że z jednej strony pojawiają się w nim wątki i ujęcia dla Leśmiana charakterystyczne, z drugiej zaś wyróżnia się on swoją rzucającą się natychmiast w oczy odrębnością.

Niewiele o nim wiadomo, w istocie nic ponadto, że ukazał się w Łące i włączony został do cyklu Ponad brzegami, choć - stwierdźmy od razu - niezbyt do niego przylega; cykl ten zresztą w ogólności charakteryzuje się tym, że składają się nań utwory o dość różnych tematach i właściwościach, może znalazły się w jego obrębie te, które w cyklach bardziej spójnych po prostu się nie mieściły, jak opowieść o zagrobowych losach bohatera arcydzieła Cervantesa (Don Kichot) czy zaskakujący i niesamowity opis muzeum figur woskowych (Kleopatra). W wydaniu swym Aleksander Madyda dokładnie podaje, gdy tylko było to możliwe, informacje o miejscu pierwodruku. Ich brak świadczy, że przed publikacją w tomie wiersz nie był drukowany lub - być może - był, ale tekst w starych czasopismach, almanachach czy antologiach nie został odnaleziony. Dwóm skazańcom nie towarzyszy tego typu wiadomość, nie możemy zatem choćby orientacyjnie zakładać, z jakiego okresu twórczości wiersz pochodzi. Gdy to wydaje się z jakichś względów konieczne lub choćby przydatne do interpretacji, nie pozostaje nic innego, jak tylko się domyślać. Daty roczne wydań poszczególnych tomów Leśmiana są znane (Łąka - przypominam - ukazała się w roku 1920), jednakże chronologia powstawania poszczególnych jego utworów kryje wiele tajemnic, można mieć wątpliwości, czy kiedykolwiek zostaną one rozwikłane, po prostu nie ma świadectw i dokumentów, które by na to pozwalały. Zresztą znajomość daty pierwodruków też oczywiście nie przesądza w większości przypadków o tym, że można datę publikacji czasopiśmienniczej uznać za choćby przybliżoną

1 Korzystam z edycji opracowanej przez Aleksandra Madydę: B. Leśmian Poezje zebrane, Toruń 2000, s. 297. 
datę powstania danego utworu. Wydaje się wszakże, iż interesujący nas w tym szkicu wiersz powstał sporo przed rokiem 1920, do sprawy tej dane nam będzie wrócić, zwłaszcza że hipoteza dotycząca czasu powstania łączy się z tym, co jest konieczne do wyjaśnienia i zrozumienia tego wiersza, stanowi nawet warunek jego właściwej lektury i interpretacji. Zanim jednak wyłożę swoje przypuszczenia, chciałbym przedstawić w miarę możliwości dokładną analizę tego ze wszech miar intrygującego utworu, pod pewnymi względami dobrze osadzonego w poetyce Leśmiana, pod innymi - wyróżniającego się swoimi niewątpliwymi, widocznymi już w trakcie pierwszego czy wstępnego czytania, osobliwościami.

Istnieje w przekazie poetyckim Leśmiana kilka wybitnych i wysoce reprezentatywnych utworów, w których występuje zjawisko dające się określić jako podwójność bohaterów. Niekiedy zaznacza się to już w tytule, by wspomnieć o jednym z najbardziej niezwykłych i najoryginalniejszych poematów, a mianowicie w Dwu Maciejach. Pojawiająca się w tej niezwykłej metafizycznej burlesce cyfra jednoznacznie wskazuje na podwójność, podobnie dzieje się w będących bezpośrednim przedmiotem przedstawianych tu uwag Dwu skazańcach. Niekiedy owa podwójność wyraża się już w tytule w sposób nieco inny, mianowicie za pomocą podobieństwa imion bohaterów, wzmocnionego rymem. Przykładem bodaj najbardziej dobitnym jest popularna ballada Świdryga i Midryga, w której wątek owej podwójności przywołany jest bezpośrednio w początkowym dystychu:

To nie konie tak cwałują i uszami strzygą, Jeno tańczą dwaj opoje - Świdryga z Midrygą.

Relacje między dwoma bohaterami mogą być rozmaite, czasem walczą oni ze sobą, jak w przywołanej wyżej balladzie, należącej do najbardziej znanych utworów Leśmiana, czy w niezwykłej opowieści, którą chyba można określić jako balladopodobną, zatytułowanej MigońiJawrzon. W tym przypadku szczególnie znaczące jest zakończenie, w którym omawiany wątek podwójności zyskuje postać nader wyrazistą:

Obaj zwarli się ściśle - z kolanem kolano, Ale tylko jednego - jak walczył - widziano.

Do obydwu mrok śmierci na palcach się skradał, Ale tylko jednego widziano, jak padał. 
Aż słońce, poranniejąc w obłokach nieśmiało,

Rozwidniło to właśnie, co nocą się stało.

Rozwidniło dwa trupy - i obok dwa ule.

I jedną niewidomską na krzaku czapulę.

Można powiedzieć, że wówczas gdy chodzi o owych podwójnych bohaterów, w równiej mierze istotna jest różnica jak i analogia. Ich wzajemne relacje objawiać się mogą w ujęciach zaskakujących. Tytułowy bohater Żotnierza, ostatniej w cyklu Pieśni kalekujących, różni się, co oczywiste, od nieporadnie wyrzeźbionej w drewnie przydrożnej figury Chrystusa, w pewnym momencie łączy ich jednak wspólny los, w istocie różnice schodzą na dalszy plan, mogą nawet się zacierać:

Pójdziemy nierozłącznie, bo wspólna nam droga,

Będzie nieco człowieka, będzie nieco Boga.

Podzielimy się męką - podzielnać jest męka! -

Wszak ta sama nas ludzka skoślawiła ręka.

[...]

Skakali jako trzeba i jako nie trzeba,

Aż wreszcie doskoczyli do samego nieba!

Rozmaite przypadki i sytuacje owych paralelnych bohaterów dzielą, jak widzimy, może to być nawet wrogość i walka (tak dzieje się w przywoływanym wyżej Migoniu i Jaworznie), jedno bezwzględnie łączy - obydwaj znajdują się w sytuacji ostatecznej. Dzieje się tak zarówno wtedy, gdy z pozoru bardzo się między sobą różnią, tak jest właśnie w Żołnierzu, jak też wówczas gdy akcent pada na podobieństwo. Przypadkiem najbardziej wyrazistym są wspominani już Dwaj Macieje. Jest to swojego rodzaju opowieść o sytuacji egzystencjalnej, z której obydwaj próbują się wyzwolić, rzecz jasna bezskutecznie, opowieść, łącząca groteskę i elementy gawędowe z eschatologią. Jest to jeden z najświetniejszych poematów Leśmiana o umieraniu i śmierci. Zacytujmy zakończenie:

Świat im w oczach zanikał... Nastały złe dreszcze.

I już świata nie było, a trwali gdzieś jeszcze...

Rzekł jeden: „Noc nadchodzi” - A drugi rzekł: „Dnieje” Tak zmarli jednocześnie obydwaj Macieje. 
Podobieństwo i różnica, analogia i kontrast to także podstawa historii Dwu skazańców. Są one nawet bardziej wyraziste niż w opowieści o smutnym losie dwóch Maciejów. Zanim wszakże tą sprawą się zajmiemy, musimy wskazać na pewną osobliwość tego utworu. Jest to wiersz o egzekucji i różnych postawach obydwu bohaterów w ostatnich chwilach życia. A więc jeszcze jeden z ogromnego zespołu wierszy Leśmiana o śmierci? Mimo swych rozmaitych osobliwości niewątpliwie tak. Większość utworów znajdujących się w obrębie tego zespołu to opowieści o umieraniu przedstawianym jako proces, czyli seria wydarzeń2; można powiedzieć, że śmierć nie jest w poezji Leśmiana faktem momentalnym, dzieje się w mniej lub bardziej wyraziście charakteryzowanym czasie, formuje się w osobliwą i na swój sposób jedyną fabułę. Takie kształtowanie ostatniej fazy ludzkiego bytowania zakłada w mniejszym lub większym stopniu narracyjność, nie przypadkiem utwory tego rodzaju są w twórczości Leśmiana balladami lub w pewien sposób do tej poetyckiej formy się zbliżają, respektując mniej lub bardziej jej gatunkowe właściwości. Jedna z nich dla wiersza będącego przedmiotem tych uwag ma szczególne znaczenie. Tak ją ujął Ireneusz Opacki w swych rozważaniach o poetyce ballady:

W balladzie sytuacja [fabularna - M.G.] się zmienia: akcja ballady nie jest akcją rozegraną w przeszłości, jest akcją rozgrywaną a k tu a ln i e. Narrator więc nie może znać pełnego jej przebiegu. Nie może być narratorem wszechwiedzącym. Siłą rzeczy staje się narratorem n a i w ny m. ${ }^{3}$

Można mieć wątpliwości, czy przymiotnik „,naiwny” został tu użyty trafnie, gdy odniesiony do opowiadaczy Leśmianowskich. Wydaje mi się, że nie, co nie sprzeciwia się temu, że Opacki wskazał na zjawisko dla wierszy narracyjnych Leśmiana podstawowe i charakterystyczne, niekoniecznie zresztą będących balladami w ścisłym sensie. Pewne z nich dają się definiować jako - pozwolę sobie na utworzenie neologizmu - balladoidy, czyli utwory w tym czy w owym z balladą spokrewnione, tak czy inaczej do niej się odwołujące, mimo wszakże tych związków nie spełniają one jednak podstawowych warunków gatunku. Zacytujmy wiersz Leśmiana in extenso:

2 Zob. moją pracę Poezja śmierci w tomie Zaświat przedstawiony. Szkice o poezji Bolesława Leśmiana, wydanie 2, Kraków 1998.

3 Cytuję za tomem: I. Opacki Ballada, oprac. Cz. Zgorzelski, Wrocław 1970, s. 31-32. Obydwa podkreślenia Opackiego. 
Widziałem dwu skazańców, co na swym uboczu

Wysłuchali wyroku pod bagnetów strażą

I na tłum zgromadzony patrzyli bez oczu, Jak ślepiec, kiedy zmierzchu wypatruje twarzą. Jeden z nich, licząc jakieś ubiegłe godziny, $\mathrm{O}$ widzenie się z ojcem poprosił nieśmiało, A drugi wnet zawołał: „Ja nie mam rodziny!" A miał ją, lecz mieć nie chciał... Tak mu się zdawało.

Śnili teraz, że chata, niegdyś ludna, traci Ich ciała, bezpowrotnie wyszłe z jej alkierza. Czuli próżnię na miarę wzrostu swych postaci. Jak klatka, z której nagle wypłoszono zwierza. Jeden z nich zapatrzony w strzęp własnego cienia, Chciwie wody zażądał wargą obolałą, A drugi wnet zawołał: „Ja nie mam pragnienia!" A miał je, lecz mieć nie chciał... Tak mu się zdawało.

Mówię tu o narracjach balladoidalnych, gdyż spora liczba utworów narracyjnych Leśmiana pod pewnymi względami wyraźnie przypomina fabuły balladowe, do nich w taki sposób się odwołuje, ale pod pewnymi względami od nich się różni. Ważne jest to, co Ireneusz Opacki pisze o wiecznej teraźniejszości, charakterystycznej dla balladowych fabuł. Jest to doniosłe także dla tego typu wierszy Leśmiana. Nie przeczy temu fakt, że występuje w nich mniej lub bardziej konsekwentnie czas przeszły. Tak też dzieje się w Dwu skazańcach, początkowe „widziałem” z pozoru przesuwa wydarzenie w przeszłość, wydaje się wszelako, że ważniejsze jest tu co innego, to mianowicie, że narrator przypisuje sobie rolę naocznego świadka, widza i że utrwala swoje postrzeganie wydarzeń. Inaczej niż w balladach w ścisłym sensie nie mają one charakteru ciągłego, w istocie ujawniają się w najmniejszych jednostkach czasu, w swojego rodzaju momentach, stają się owymi chwilami, w których dzieje się coś niezmiernie doniosłego. I to one właśnie znajdują się na pierwszym planie, nie znamy antecedencji, konsekwencji możemy się jedynie domyślać. Sugeruje je tytuł, a także w ogólności sytuacja, której następstwa są oczywiste. Podkreślaniu roli teraźniejszości służy to, co stanowi przytoczenie słów bohaterów, w interesującym nas przypadku - dwu skazańców.

Zgodnie z tradycją ballady - wystarczy przypomnieć choćby Mickiewiczowskich Trzech budrysów - bohaterowie wypowiadają się, przytoczenia ich 
słów są na ogół wobec siebie paralelne, ale muszą się też różnić. Motyw mówienia występuje $\mathrm{w}$ wielu wierszach Leśmiana. Pojawiają się także wskazania sugerujące niemal epickie traktowanie sprawy przytoczeń. Niekiedy są one całkiem konkretne, choć bywają wypowiadane w kontekście funeralnym. Na przykład:

W kraju bardzo dalekim, smucąc się ku wiośnie, Tak synowie swym ojcom mówią bezlitośnie [...] inc. W kraju bardzo dalekim

Czasownik „mówić” pojawia się u Leśmiana w najróżniejszych kontekstach. Także w sytuacjach ostatecznych, w tym niekiedy w ujęciach odwołujących się do wątków religijnych, odbiegających zresztą od wszelkiej ortodoksji:

Mówmy wobec jego zgonu

To, co mówi dzwon do dzwonu

Późnym wieczorem

W przeddzień swego zmartwychwstania

Mówienie przestaje być tylko sztuką, nad którą panują istoty ludzkie, w pewnych przypadkach staje się właściwością natury. Tak dzieje się w piątym epizodzie poematu Łąka, chyba kulminacyjnym w tej niezwykłej opowieści, interesującym też z tego względu, że w nim wyraził się literacki program poety, widoczny także w innych utworach, by przypomnieć tylko w dużej mierze programowe Stowa do pieśni bez stów:

Mówimy śpiewający, bo łatwiej przy śpiewie

Mówić o tym, co było, a czego się nie wie...

$\pm a q k a, \mathrm{~V}$

Mówienia w Dwu skazańcach oczywiście ze śpiewem zestawiać nie należy, nie jest to - by tak powiedzieć - poetycki program formułowany pod szubienicą. Nie jest to zresztą również rozmowa między dwoma bohaterami. Nie wymieniają oni kierowanych do siebie opinii, składają swojego rodzaju "deklaracje”, formalnie podobne, choć - i fabularnie, i myślowo - przeciwstawne. Narrator jest tu swojego rodzaju świadkiem strasznego wydarzenia, co zostało uwydatnione przez incipitowe „widziałem”. W zasadzie niczego on nie komentuje, choć taką rolę mogłoby grać powtórzone w obydwu strofach, 
paralelne względem siebie „Tak mu się zdawało”. Mówienie służy tutaj wyrażeniu odmiennych postaw w sytuacji ostatecznej, obydwaj bezimienni bohaterowie czekają przecież na egzekucję.

I w tym miejscu właśnie dochodzimy do fundamentalnej osobliwości tego wiersza na tle ogromnej większości (a może wszystkich) fabuł składających się na Leśmianowskie utwory, będące klasycznymi balladami, ale też tak czy inaczej kształtowanymi opowieściami, które pozwoliłem sobie określić mianem balladoidów. Nie ma w nim, co zrozumiałe, szeroko przedstawionych realiów, trudno ich oczekiwać w niewielkiej, choć niezwykle zagęszczonej narracji. Jedno wszakże jest pewne: wydarzenia te nie dzieją się gdzieś między niebem a ziemią, wśród słynnych przestworzy. Taką ewentualność musimy wykluczyć, mimo że mamy niewiele danych, by przestrzeń tę scharakteryzować. Wszystko jednak wskazuje, że bardziej chodzi tu o stoki warszawskiej cytadeli w pierwszej dekadzie XX wieku niż o te rejony, które są na ogół przedstawiane lub tylko wzmiankowane w utworach poety. To z pewnością nie jest przestrzeń fantastyczna. Niewiele o niej w wierszu się dowiadujemy, możemy jednak - jak się zdaje - określić ją jako historyczną. Szubienic raczej nie wprowadza się do zaświata przedstawionego, należą one - niestety - do realiów ziemskich, trudno byłoby je przetransportować w te rejony, które poetę od najwcześniejszych czasów fascynowały. Czyżby był to wiersz napisany ku chwale bojowników, takich na przykład postaci jak Stefan Okrzeja czy Józef Montwiłł-Mirecki, którzy stali się nie tylko bohaterami, ale też figurami symbolicznymi? Innymi słowy: czy w wierszu tym chodzi o odwołania do rewolucji roku 1905 i tego, co po niej nastąpiło?

W istocie nie umiem odpowiedzieć na te pytania, aczkolwiek uważam, że można, a w istocie należy, je zadać. Leśmian - zapewne w dużej mierze słusznie - uchodzi za poetę, do którego utworów realia świata, w którym przyszło mu istnieć, wstęp miały wysoce ograniczony, za poetę oddanego w pełni metafizyce i fantastyce. Czy jednakże takie wiersze jak właśnie Dwaj skazańcy czy wspaniały Pejzaż wspótczesny nie świadczą, że realia owe też przyciągały jego uwagę? Być może warto w ten sposób wskazać na rozległość jego poetyckich możliwości? Wielcy poeci sprawiają czytelnikom niespodzianki nawet wówczas, gdy nie wykracza się poza, z pozoru dobrze znany, korpus ich utworów. 


\section{Abstract}

\section{Michał Głowiński}

THE INSTITUTE OF LITERARY RESEARCH OF THE POLISH ACADEMY OF SCIENCES (WARSAW)

An Understudied Poem by Leśmian

Głowiński proposes an interpretation of Bolesław Leśmian's little-known poem "Dwaj skazańcy" [Two Condemned Men]. Published in the collection Łąka [Meadow] in 1920, the poem is likely to have been written much earlier. It shows some characteristics typical of Leśmianss poetry, such as narrativity, extensive use of the protagonists> own words and the protagonists> duality (their similarities are as important as their differences). The poem s particularity lies in its real-life setting, possibly during the Russian Revolution of 1905 .

\section{Keywords}

parallel protagonists, ballad, quotation, realities of 1905 